\title{
USING THE ELEMENTS OF TRADITIONAL CULTURE IN THE TEACHING PROCESS FROM THE PERSPECTIVEOF ETHNOPEDAGOGY AND ETHNOLOGY
}

\author{
KATARÍNA SLOBODOVÁ NOVÁKOVÁ \\ Department of Ethnology and World Studies, University of Ss. Cyril and \\ Methodius in Trnava \\ Námestie J. Herdu 2, 91701 Trnava, Slovakia \\ E-mail address: katarina.novakova@ucm.sk \\ ORCID: http://orcid.org/0000-0002-8331-7040
}

\section{MARIANA SIROTOVÁ}

Department of Pedagogy, University of Ss. Cyril and Methodius in Trnava

Námestie J. Herdu 2, 91701 Trnava, Slovakia

E-mail address: mariana.sirotova@ucm.sk

ORCID: https://orcid.org/0000-0003-1599-9702

MARTIN URBAN

Department of Music Culture, Matej Bel University

Ružová 13, 97411 Banská Bystrica, Slovakia

E-mail address: martin.urban@umb.sk

ORCID: http://orcid.org/0000-0001-6287-8984

\section{JEROME BAGHANA}

Institute of Cross-cultural Communication and International Relations

Belgorod State University

Studencheskaya14, 308015 Belgorod, Russia

E-mail address: baghana@yandex.ru

ORCID: http://orcid.org/0000-0001-6061-3288

\begin{abstract}
Aim. The presented study aims to briefly present the possibilities of using and implementing elements of traditional culture in the teaching processat primary and secondary schools in Slovakia. It points out all the aspects and factors that enter the educational process when using these elements.
\end{abstract}


Concept. Regional education is being applied in the educational environment of schools in order to develop the children with the right stimuli. The aim of including knowledge and partial topics of traditional folk culture in teaching is mainly to motivate students and arouse their interest in the cultural heritage of their ancestorsand country. We use comparative methods to clarify the relationships between ethnology, pedagogy, ethnopedagogy, and their interconnection in the pedagogical process. We define the primary goals of regional education, methods, and forms of teaching regional education, focusing on interactive forms of teaching.

Results and conclusion. The values and the importance of traditional culture should be assessed in terms of the functions of education and training ina broader societal perspective. Regional education should make a significant contribution to the transmission of culture in education. The research results indicate the need to implement ethnopedagogy into the current educational process at all levels of education and scientifically verify its success.

Research restrictions. The main research problems or limitations are related to the factthat this subdiscipline has not yet received attention in Slovakia.

Originality. The paper presents an original view of ethnopedagogy and regional education issues through the lens of ethnology and pedagogy and defines key subjects of interest focusing on Slovak/Central European needs and contexts. culture

Key words: ethnology, ethnopedagogy, folklore, regional education, traditional

\section{INTRODUCTION}

$\mathrm{T}$ The reforms of the school systemstaking place in all countries of the world have a common denominator: the effort to streamline the educational process and operation. However, there was and still is a constant conflict between the school's possibilities and society's requirements. Practice brings many changes all the time. The volume of new knowledge in individual scientific disciplines is growing, while society, life philosophy, strategy, and living standards arechanging (Kancír, 2011). The response to these changes in school systems is slow, as it is a change in the content and education itself. Therefore, in the framework of constant reforms, there are discussions of "permanent curricular transformation" (Kancír, 2011, p. 37).

Education aimed at gaining a positive relationship with one's homeland, nation, and people is nothing new in a school theory and practice. Even Czech philosopher, pedagogue, and theologian Comenius, with his principle of succession-from simpler to more complex, closer to more distant-drew attention to the initial knowledge of the pupil's primary environment as a starting point for further cognition (Borbély, 2012). Initial knowledge of the pupils is logical in connection with the strategic goals of education, which have been declared by several national, European, or world documents, in the proposed concepts of education in Slovakia and the national education programmes.

In recent years, regional education has been gaining support in school activities through school education programmes. Gradually, regional education is being taught at more schools. Regional education is a cross-cutting theme that deals with valuable tangible and intangible cultural heritage. In Slovakia, 
regional educationis becoming increasingly applied in the educational process due to the need to develop children with simple to more complex stimuli. Therefore, it is necessary to follow these requirements already during primary education. The paper aims to point out how regional education can be thematically linked withseveral subjects through various stimuli and activities. Activities can be carried out in Slovak language and literature lessons, homeland studies, art education, mathematics, IT classes, and physical education (Kaščáková, 2014).

It is known that the region and its elements represent an important form-creating source of education, providing new opportunities for transforming traditional teaching, but above all, bringing the life of the school closer to the real world. A suitable type of didactic communication of a pupil with a region (the so-called regional or domestic principle) is regional education, which through a living spectrum of experiences and visual aids in a familiar environment, opens the relational dimension of the pupil to his/her home, to his/her values, develops aesthetic and patriotic feelings (Borbély, 2012, p. 75). Thus, regional education can be understood as a means of patriotic and natural science, technical, linguistic, art, mathematical, and physical education, which aims to awaken and develop individuals' perceptual and emotional relationship to the beauties of nature and specific creative criteria (Čellárová, 2002).

Finally, regional education participates in the all-round development of the pupil's personality and leads, in addition to highlighting national or local awareness, to the knowledge of cultural and natural values, relationship to their place of residence, municipality, or region, which is a supremely current part of lifelong learning and knowledge.

\section{ETHNOPEDAGOGY}

The topic of traditional folk culture in teaching, especially in the subjects of regional education, is closely related to the cross-sectional topic of multicultural education, but in its content, it deals even more deeply with living and valuable tangible and intangible cultural heritage. The subject and focus of regional education, its content, and development are mainly dealt with by ethnopedagogy.

Ethnopedagogy as a part of pedagogical sciences deals with ethnic groups in general. As with other emerging subdisciplines, there is no fully and clearly defined subject of interest.However, the key subjects of interest include in particular: intercultural differences in family and upbringing; the origin and development of ethnic, confessional attitudes, opinions, prejudices, stereotypes in children and young people and their influence on school education; intercultural differences in education; intercultural differences between pupils, teachers, their attitudes and views; teaching minorities in the majority environment, etc. (Průcha, 2002, p. 196).

Abroad, the term intercultural education, multicultural education, interethnic education are more often preferred to refer to such a subdiscipline. In Cen- 
tral and Eastern Europe, the term ethnopedagogy has become popular in the pedagogical sciences (e.g., Volkov, 1999), which is why we also use it in this paper.

Ethnopedagogyis related to many disciplines that are in some way connected with selected dimensions of the region that use regional elements in education and training following the regional educational principle (Kancír, 2011). Jan Průcha characterised ethnopedagogy as a field of pedagogical theory and researchthatdeals with topics and issues of education and training of members of ethnic, racial, religious, and other minorities (Průcha, 2003). In Slovakia, this field of pedagogy was developed by Vlasta Cabanová, who has analysed it in the context of the importance of education and training of regional minority cultures living in Slovakia. She considers minorities living in the regions to be subcultures, with which ethnology completely disagrees. She defines ethnopedagogy as a borderline discipline that examines the choice, scope, and extent of the use of regional local culture in schools' educational process. According to Cabanová, ethnopedagogy deals mainly with:

- selecting valuable elements of a folk culture characterised by their regionalityto be included in the content of education (what);

- the scope of implementingeducationalprojects with regional content to other educational content (how much);

- principles of the most appropriate way of organising this content into the curricula and textbooks (how) (Cabanová, 2005, as cited in Kancír, 2011, p. 39).

\section{CHARACTERISTICS OF REGIONAL EDUCATION}

Regional education is multi-aspectual and multidimensional because it combines knowledge of patriotic, linguistic, movement culture, and others, aiming to awaken and develop an individual's emotional relationship withthe creative activity of the inhabitants of a particular area. Regional education participates in the overall development of pupils' personalities and leads to increased national awareness and emotional relationship with their place of residence, municipality, region, and homeland.

By regional culture, we understand a set of products (tangible and intangible) of human activity tied to a specific municipality or region. Regional culture includes local and regional cultural heritage and livingcultural expressions that function duringeveryday life, public holidays, and celebrations. Regional culture builds on regional cultural traditions and considers them an essential part of historical memory and a source of identity of a municipality or region.

The primary aspect ofapplying regional elements and phenomena in the educational process is being aware of the concept of a region (a territorial unit), which implies the basic principles and knowledge for the area. The regions arose from the need to limit themselves from the state or other regions. The goal of the region is to define its territory. The encyclopedia of folk culture of Slova- 
kia (1995) defines this term as "area" with an occurring phenomenon or a set of phenomena in its own characteristic composition. The most important factors are the language and the whole structure of folk culture. However, the division of traditional culture into regions isnot precisely specified or stable because it depends on the observed phenomena, such as architecture, folk clothing, dance culture, etc. Each region has its peculiarities, local and regional heritage, holidays, festivities, and customs. The aim is to provide ideas for implementing the cross-cutting theme of regional education into practice and for pupils to learn as much as possible in a playful way about the region in which they were born or live. Regional education should contribute to this knowledgeas well (Lenovský, 2018a, 2018c). In each activity and project in regional education, thegoal is to playfully convey information about the region, the past of the municipality, ancestors and to develop children's positive attitudes towards the region (homeland).

\section{AIMS OF REGIONAL EDUCATION AND THE DEFINITION OF COMPETENCIES OF EDUCATION PARTICIPANTS}

Regional education is being increasingly applied in the schools'educational environment, responding to the need to develop the child with the right stimuli. These right stimulican be intensively developed during formal education. The author Dana Kaščáková states that regional education helps to form personal and interpersonal competencies of students such as healthy self-confidence; racial, ethnic and social tolerance towards "others"; acceptance of other nations' traditions and culture; the universal values of freedom; communication skills; information management and its use in everyday life; teamwork (2014. p. 8).

In this sense, patriotic and national education tasks are also performed as part of the personality and formation of the relationship towards the world and life. JánDanek(2019) states that the connection of narrower, regional elements of education with broader aspects of society as a whole is in the competence of the teacher's educational tasks. Other competencies of teachers include:

- leading pupils towards learning about the heritage of our ancestors,

- choosing the right and age-appropriate methodological procedures,

- motivating pupils correctly, influencing them positively, and striving for the education of a personality that is and will be proud of its roots, culture, region, and homeland.

For these reasons, regional education aims to inspire children and young people to notice and record interesting information from their surroundings and learn how to use it in life. We do not understand regional education as an isolated phenomenon but as an integral part of preparing the young generation forlife in our society. We must try to raise children in a non-violent way. The pedagogical personality, competence, readiness, and especially 
the knowledge of the region are important in the realisation of the aims of regional education because a teacher can become the bearer and disseminator of values such as love and respect for the native community, home, and homeland. These personal prerequisites enable the teacher to carry out the following activities within the framework of regional education (Masariková, 2007):

- to get to know owncity, its history, historic buildings, and present life;

- to cultivate a positive attitude of the individual to the birthplace, region, homeland, culture;

- to increase the level of knowledge of pupils through projects, make lessons more interesting, creative, provide pupils with elementary knowledge;

- to teach pupils how to work in groups, search for information from the Internet, process it into projects, and present projects.

These activities determine the development of students' relationship to the region, their community, home, and homeland. In addition, part of regional education is traditional folk culture.

The aim of including knowledge and partial topics of traditional folk culture in teaching isto motivate pupils and arouse their interest in the history of their municipality or city, cultivate a local identity, develop an interest in their roots, history of their family, etc., and to create preconditions for cultivating and developing a sensitivity to the beauties of their region, nature, architecture, folk art, and getting to know theirancestors' cultural heritage.

The Government of the Slovak Republic undertook to implement Recommendations on the safeguarding of traditional culture and folklore and The convention for the safeguarding of the intangible cultural heritage, and The convention on the protection and promotion of the diversity of cultural expressions approved by the General Conference of UNESCO. It is recommended to include the topic of cultural heritage in a non-violent way in the teaching of several subjectsand in the form of projects, excursions, etc. The subjects such as art, music, literary and ethical education, work teaching, history, science, homeland studies, and geography are particularly suitable. Within the school curriculum, the cross-cutting theme's content can be included in optional subjects, such as regional education, regional history, geography, art education, choir singing, children's musical theatre, literary-dramatic theatre, etc.

Research in the field of ethnopedagogy focuses on how educational activities in the framework of regional education implement knowledge and insights from the history and culture of the specific municipality, city. It also examines whether, for example, the practical use of regional historical examples, individual phenomena of traditional culture (customs, songs, legends, fairy tales, dance, games, etc.) is included in the educational process.

The basis of our cultural identity and a source of historical consciousness, education, and knowledge of cultural diversity is traditional folk culture - the culture that the broadest strata of the population have created, in which they lived and still live. 


\section{METHODS AND FORMS OF TEACHING REGIONAL EDUCATION}

In regional education, it is possible to use a wide range of methods and forms of work to make it interesting and stimulating for pupils. Thanks to the use of appropriate teaching methods, there is a close interaction between a teacher and a pupil. For this reason, it is necessary to use mainly interactive methods. Kaščáková (2014) presents the following methods and forms of work: the first group consists of methods for informing pupils and creating knowledge. Here the author includes an information-receptive method (informing pupils using words, images), explanation (if the curriculum is demanding, various complex lessons, rules, laws are clarified, logic serves as the basis, and logical procedures are applied), description (associated with observation) and the reproductive method (durability of knowledge through repetition).The second group consists of interactive methods such as problem interpretation, heuristic method (creative problem solving), brainstorming (with the emphasis on the quickest possible collection and writing of ideas and information), and storytelling (used if the curriculum is not demanding and if it has mainly an educational mission; focused on the ideas, feelings, and imagination of the pupil). In the group, there are also activities such as conversation (an important teaching method that activates pupils but requires thorough teacher training), dialogue and discussion (leading to an increased personal understanding or a group consensus), didactic play, and staging method (role-playing method, simulation of specified situations). The third group consists of the forms most often used in regional education. Almost all of them are used depending on the pupils' age and the lesson's goal and content, methods such as individual work, pair and group teaching, walk, trip, excursion, project teaching, and currently also work with Information and Communications Technology are applied.

The organisational form of teaching is understood as a time-limited teaching unit, which has its precisely dimensioned teaching and educational goals and fulfils educational and upbringing tasks. It uses many teaching methods, which form an organic unity of didactic procedures, and it regulates the activity of the object and the subject according to age, pedagogical, physical, and mental peculiaritiesin a specific way. The most commonly used is a mixed type lesson. During this lesson, there is the presentation of new knowledge and the formation of the personal competencies of pupils, their values, and their relationship with society. Thus, regional education significantly contributes to the formation of a relationship with society. For this reason, it is necessary to pay more attention to the elements of regional education in the education of children and youth, such as traditional folk culture. 


\section{EXAMPLE OF A THEMATIC UNIT ON TRADITIONAL FOLK CULTURE}

Traditional folk culture is a collection of tangible and intangible products of human activity created in traditional societies. It was passed down from generation to generation by word of mouth, imitation, and, to a much lesser extent, written form. Traditional folk culture as a comprehensive and living system gradually disappeared with society's modernisation; its phenomenon became a source of cultural and social identity, historical consciousness, patriotism and education, knowledge of cultural diversity, instruments of tolerance, civic cohesion, and understanding between nations. It is part of the material and spiritual wealth of the nation. It is preserved as a manifestation of local, regional or cultural heritage. We perceive traditional folk culture as a form of cultural expression supporting cultural identity preservation (Lenovský, 2018a, 2018b.). We understand cultural identity as a set of attitudes, habits, traditions, values, interpretations, and self-interpretations, ways of thinking, feeling, and acting (patterns of behaviour), which characterise an organised group of people, its collective, common creation.

Topics that can be used within regional education in the educational process are the following:

- traditional material culture: folk architecture, domestic and traditional handicrafts, traditional crafts (their history), food and its production, clothing (costumes), fine arts, etc.;

- traditional intangible culture: oral traditions and expressions, including language (folk literature, dialects), performing arts (folk music, songs, dances, games), social practices, customs, rituals and ceremonial events, traditions associated with religious holidays (for example, Christmas, Easter, etc.), customs and traditions related to nature and universe, folklore traditions (manifestations of traditional folk culture: oral, play, dramatic, vocal, dance and music).

\section{CONCLUSION}

The aim of this article was to briefly present possibilities we have usingthe elements of traditional culture in teaching, whether in primary orsecondary schools. The question of values and the importance of traditional culture should be assessed in terms of functions of education and training and a broader societal perspective. Practice and topical discussions point to the fact that value education and culture transmission in education face many problems. All factors involved in the development of the student's personality should participate in their solution. Regional education should make a significant contribution to this transmission. Because family upbringing is followed by school education, it is necessary that teachers and parents of pupils also mutually cooperate to perform a cultural-transmissive function 
in the integration of values and culture into education, aiming to mediate historical culture and to ensure continuity in time, the development of national, regional, or local identity and the protection of cultural heritage. Education and culture are understood as two successive processes because the implementers of the cultural-transmissive function must have knowledge of science, technology, art, work skills, spiritual and moral values for pupils to learn to understand the culture, to develop good habits, to perceive the importance of human values, and, subsequently, to become their bearers and representatives (Labudová-Lobotková, 2019). Thus, it is necessary to start implementing ethnopedagogy in the current educational process at all levels of education and to scientifically verify its success in creating a positive relationship between children and youth with the country, culture, and social values.

\section{ACKNOWLEDGMENT}

The paper was supported by the research project VEGA 1/0383/18 and APVV 20-0263 Current Identification, Cultural and Revitalisation Processes in a Minority Environment.

\section{REFERENCES}

[1] Danek, J. (2019). Value orientation in the process of the word's global direction and its problems. Journal of Interdisciplinary Research, 9(2), 22-24.

[2] Danek, J. (2019). Philosophical and societal elements of human upbringing. XLinguae, 12(4), 66-76.

[3] Danek, J. (2018). Communication in social and study context. Slavonic Pedagogical Studies Jour$n a l, 7(2), 323-338$.

[4] Cabanová, V. (2005). Tvorba obsahu vzdelania v regionalisticky orientovaných školách [Creation of educational content in regionally oriented schools]. Praha: Epocha.

[5] Lenovský, L. (2018a). The language, identity, and culture of ethnic minorities in the Central European contexts. XLinguae, 11(4), 125-142.

[6] Lenovský, L. (2018b). The relation of language, culture, and identity in the environment of ethnic minorities. Slovaca Slavica, 53(3-4), 243-251.

[7] Lenovský, L. (2018c): Ambivalence in interpretations of multiculturalism as a problem of forming the ethico-axiological foundations in an integrated society. European Journal of Science and Theology, 14(4), 49-58.

[8] Labudová E., \& Lobotková, A. (2019). Tradície a život etnickej skupiny Huncokári v poznaníżiakov [Traditions and life of the ethnic group of Huncokars in the knowledge of students]. In Minority v Európe II. Zborník z medzinárodnej konferencie I (pp. 118-124). Nadlak: Vydavatel'stvo Ivana Krasku.

[9] Kaščáková, D. (2014). Regionálnavýchovavovyučovacomprocese [Regional education in the teaching process]. Bratislava: Metodicko-pedagogické centrum.

[10] Kancír, J.(2011). Environmentálna a regionálna výchova v kontexte kurikulárnej transformácie [Environmental and regional education in the context of curricular transformation]. Geografhiacassoviensis $V, 1,37-41$.

[11] Ospanova, Z., Tolybayeva, K., Nurkenova, S., Duisekova, K., \& Baltabayeva, G. (2020). Lingua and culture study research on indirect communication cognitive metaphor. XLinguae, 13(2), 157-165. 
[12] Petlák, E. (2020) Motivation in the educational process. Slavonic Pedagogical Studies Journal, 9(2), 106-114.

[13] Průcha, J. (2002). Etnopedagogika [Ethnopedagogy]. Pedagogika, VII, 195-205.

[14] Průcha, J., Walterová, E., \& Mareš, J. (2003). Pedagogický slơník [Pedagogical dictionary]. Praha: Portál.

[15] Zastková, Z. (2019). Current transformations of education - cooperative learning strategies. Slavonic Pedagogical Studies Journal, 8(2), 347-356.

[16] Zelina, M. (1996). Stratégie a metódy rozvoja osobnosti dietáata [Strategies and methods of child personality development]. Bratislava: Iris. 